\title{
A controvérsia sobre a industrialização na Primeira República
}

\author{
Flávio A. M. de Saes
}

As polêmicas a respeito da industrialização na Primeira República não se restringem, em geral, a limites estritamente acadêmicos pois os argumentos apresentados deviam, à sua época, servir de apoio a propostas de política econômica (ou à crítica de políticas em vigor) e à compreensão do alinhamento político de determinados grupos sociais. Por esse motivo, tais polêmicas não perderam atualidade: muitas das questōes de fundo aí presentes são recolocadas hoje, por vezes de modo muito semelhante ao dos anos 60 e 70.

O objetivo deste artigo não é, portanto, o de encerrar as polêmicas a respeito da industrialização na Primeira República ao indicar teses e posições corretas. Pretende-se apenas fazer um balanço da controvérsia em algumas de suas principais vertentes, indicando, sempre que possível, a atualidade das questões colocadas em foco.

Não se pretende, também, ser exaustivo no exame das inúmeras contribuições ao debate. A escolha de alguns autores, tidos como representativos de determinadas posturas, envolve as limitaçōes e preferências do autor. Daí existir grande risco de exclusão de obras de grande relevância para a discussão do tema. Vale lembrar ainda que a exposição não segue a ordem cronológica das obras comentadas pelo fato de centrar-se apenas em algumas questões particularmente importantes para a discussão do tema.

Finalmente, cabe registrar que não há intenção de reconstituir o processo de industrializaçāo em si, mas apenas alguns aspectos da controvérsia que se estabeleceu em relaçāo a ele.

\section{A Indústria Brasileira nos anos 30: a polêmica entre Furtado e Peláez}

A discussão de nosso tema - a industrialização na Primeira República nos conduz a um ponto de partida que se situa um pouco além do final daquele período. A análise de Celso Furtado sobre o crescimento industrial dos anos 30 e as críticas a ele formuladas por Carlos Manoel Peláez antecipam os principais argumentos utilizados nas teses a respeito da indústria na Primeira República. Além disso, expōem de modo bastante claro as divergências teóricas e ideológicas presentes no debate sobre a industrialização.

Por isso, justifica-se o exame preliminar desta polêmica apesar de seu objeto se situar fora do período da Primeira República. Cumpre notar também que não se trata propriamente de uma polêmica e sim de críticas expostas por Peláez à obra de Celso Furtado, Formação Econômica do Brasil (1968). 
De que modo a indústria aparece na análise feita por Furtado? Sem pretender reconstituir os eventos históricos, o autor não faz referências às origens da indústria no Brasil. A indústria passa a interessá-lo quando se processa o "deslocamento do centro dinâmico" da economia brasileira nos anos 30: a atividade voltada para o mercado interno, e não mais a agroexportadora, passa a ser o elemento decisivo na determinação do nível de investimento da economia. Como se processa esse deslocamento do centro dinâmico?

Furtado entende ser o resultado da crise econômica mundial deflagrada em 1929 e que se estende pelos anos 30 e também da política econômica adotada pelo Governo brasileiro para enfrentar a crise. Vejamos os principais argumentos do autor.

A crise mundial atinge o setor cafeeiro no Brasil no momento em que já se definia uma situação de superprodução estrutural; como resultado, há substancial declínio do preço do café no mercado internacional e a formação de excedente de produção. $O$ Governo Washington Luís havia optado por não continuar com a defesa do café (via coinpra de estoques excedentes) pela impossibilidade de contrair empréstimos externos. Após a Revolução de 30, o Governo Vargas decide retomar a defesa do café - tendo em vista não só a pressão dos cafeicultores, mas também os "interesses nacionais" -, por meio de novos instrumentos. A nova política de defesa do café, que se fazia via compra dos estoques excedentes do produto e da queima da parte invendável desses estoques, utilizava recursos provenientes, para Furtado, da expansão do crédito. Entende o autor que, por esse motivo, o Governo brasileiro transformava a política de defesa do setor cafeeiro em programa de "fomento da renda nacional", "em verdade, construindo as famosas pirâmides que anos depois preconizaria Keynes" (FURTADO, 1968, p. 203). Vejamos por quê.

A compra do excedente da produção cafeeira evitava o declínio substancial da renda interna: o café continuava a ser colhido, o emprego no setor nâo se reduzia, mantendo-se, em conseqüência, o nível da demanda agregada. Ao mesmo tempo, o desequilíbrio externo, fruto do declínio dos preços do café no mercado internacional e da receita de divisas do Brasil, provocava brusco aumento do preço dos produtos importados em função da desvalorização da moeda nacional diante da estrangeira. Como resultado, a demanda interna, que antes se resolvia, em grande parte, pela compra de importados, volta-se agora para a produção interna, já que seus preços relativos, diante dos importados, haviam sofrido grande redução.

Percebe-se, assim, como se processa o "deslocamento do centro dinâmico" da economia brasileira: antes situado nas exportaçōes, passa agora para a

A analise de Celso Furtado sobre o crescimento industrial dos anos 30 e as críticas a ele formuladas por Carlos Manoel Peláez antecipam os principais argumentos utilizados nas teses a respeito da indústria na Primeira República. procura para o mercado interno. Esta se volta principalmente (não exclusivamente) para a indústria, ensejando o rápido crescimento da produção industrial brasileira a partir de 1933, inclusive com a instalação de uma indústria de bens de capital (id., ibid., cap. 31 e 32 ).

Este é, a nosso ver, o mecanismo fundamental definido por Furtado para explicar o processo de industrialização que deslancha nos anos 30 . Aí estão presentes alguns dos elementos que, em formulaçōes mais gerais, constituem a tese da industrializaçāo por substituição de importaçōes. A par da interpretação do crescimento industrial dos anos 30, havia, implícitas na análise, certas conclusōes de ordem mais geral: em primeiro lugar, teria sido durante a crise 
econômica mundial dos anos 30 , marcada pela ruptura das relaçōes econômicas do Brasil com o exterior (exportaçōes, importaçōes, movimento de capital), que a economia brasileira encontrou os meios para industrializar-se; em segundo lugar, que a intervenção do Estado (via política de defesa do café, política cambial, etc.) teria sido a outra condição para garantir o sucesso da industrialização nos anos 30. Nessas duas conclusões estavam embutidas a negação de dois pilares da Teoria Econômica: a Teoria das Vantagens Comparativas e o Liberalismo Econômico. A mensagem contida nessas análises é de que o desenvolviInento latino-americano (identificado, em grande medida, com a industrializaçāo desses países) dever-se-ia fazer negando a especializaçāo primário-exportadora (defendida pela Teoria das Vantagens Comparativas) e contando com a intervençāo do Estado, principalmente por meio do planejamento econômico (em claro conflito com a receita liberal de atuação do Estado na economia). Estas conclusōes, apenas insinuadas no texto de Furtado, estavam presentes de modo mais claro na produção da CEPAL, com a qual, certamente, Furtado se identificava.

As críticas de Carlos. M. Peláez a Celso Furtado, organizadas a partir de informações empíricas, tinham como alvo as conclusōes de ordem política expostas acima. Peláez (1968) faz a crítica da chamada "Teoria dos Choques Adversos", em especial na formulação por ele atribuída a Furtado. Seus principais argumentos sugeriam que:

a) a política de defesa do café não foi feita com base em expansão do crédito, como indicava Furtado; para tanto, teriam concorrido, primeiro, vultoso empréstimo externo e, em seguida, os recursos provenientes de imposto sobre as vendas de café:

b) a recuperação da economia brasileira, nos anos 30 , "repousou sobre fatores externos, tanto diretos, mediante o balanço de pagamentos, como indiretos, através do efeito que tiveram sobre o déficit orçamentário, em virtude da queda das importaçōes..." (PELÁEZ, 1968, p. 36). Descarta, deste modo, a hipótese de que a procura para o mercado interno tivesse sido a responsável pela recuperação da produção brasileira.

Para Peláez, portanto, o crescimento industrial brasileiro nos anos 30 nāo decorre da crise e da intervenção heterodoxa do Estado. Este nāo teria fugido aos princípios do orçamento equilibrado (ao financiar gastos por impostos e empréstimos externos) e a recuperação da economia seria devida principalmente ao setor externo.

Nāo cabe a nós, neste momento, realizar o balanço dessa polêmica', mas apenas mostrar como ela cristaliza duas posturas distintas quanto ao processo de industrialização, posturas essas que serão retomadas na discussão da indústria durante a Primeira República. De um lado, seguindo os passos de Furtado (e da corrente da CEPAL), aqueles que entendem que a industrialização brasileira nasce da crise do setor exportador e graças a certo tipo de intervenção do Estado. De outro, os que entendem ser a expansão das exportações o elemento impulsionador da indústria (identificando-se, nessa medida, com a análise de Peláez.).
... foi a crise das exportaçōes que propiciou o crescimento da indústria? ou foi a expansão das exportaçōes que garantiu condiçōes propícias para o desenvolvimento. industrial?

1 Sobre o bajanço, consultar: Stlber, toma̧̧äo econômuca do Brastl, 1977, p. 173-207 e Surigan, Indhistria trassleza, 1986, p 58-66. 
Essa polêmica, que nasce no estudo da década de 1930, se transpõ̃e para a Primeira República e constitui um dos focos principais da controvérsia sobre a industrialização nesse período, corno observamos a seguir.

O núcleo inicial da controvérsia: "Teoria dos choques adversos" ou "Industrialização induzida pelas exportaçōes"?

Durante longo tempo, as discussōes sobre a indústria na Primeira República (principalmente entre economistas) recolocou a questão já exposta para os anos 30: foi a crise das exportaçōes que propiciou o crescimento da indústria? ou foi a expansāo das exportaçōes que garantiu condiçōes propícias para o desenvolvimento industrial?

A tese de que a indústria nacional crescia nos momentos de crise das exportaçōes não era nova, embora não tivesse sido formulada de modo preciso. Em particular, a Primeira Guerra Mundial, período de crise do setor externo, era vista como fase de expansão da atividade industrial pelo bloqueio das importaçōes que atendiam ao mercado brasileiro. Se esta tese aparece de modo genérico em obras como as de Caio Prado Jr. (1970, p. 261) e Nelson Werneck Sodré $(1967$, p. 311) - apenas para citar dois autores bastante conhecidos -, em Roberto Simonsen ela ganha contornos mais precisos.

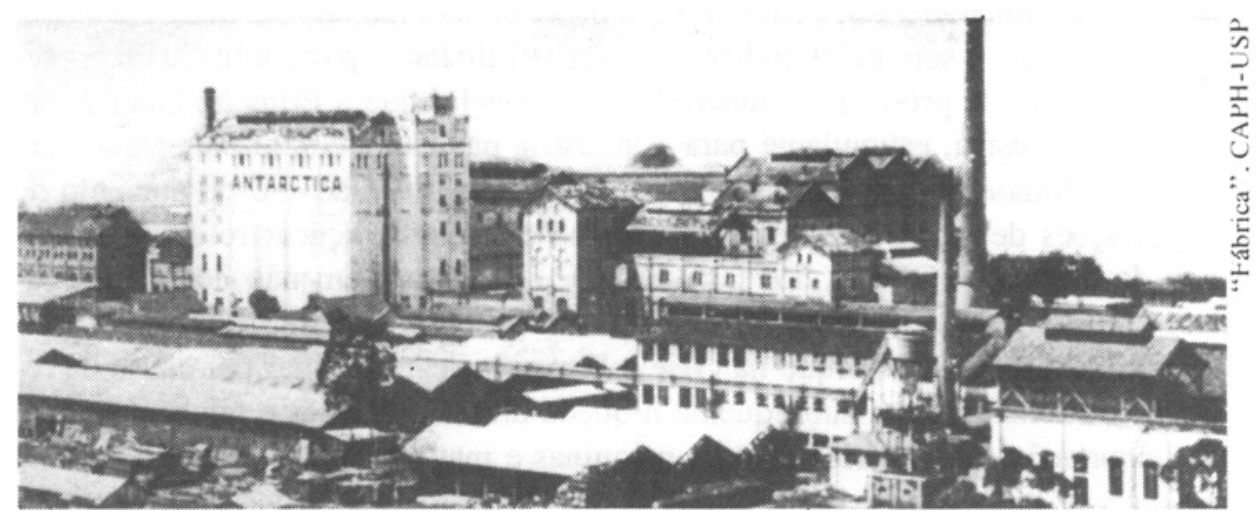

O ponto de partida de Simonsen é o dado censitário de 1920 que mostra terem sido fundados, entre 1914 e 1919, 46,5\% dos estabelecimentos industriais existentes em 1920 no Brasil. Curiosamente, Simonsen utilizava este dado também no sentido contrário ao usual, pois afirmava:

"Não procede, pois, a afirmação de que a indústria brasileira originou-se apenas da guerra européia. Teve esta, de fato, uma pronunciada influência no seu desenvolvimento posterior, por ter provocado uma notável diversificação na fabricação de novos produtos. As necessidades do consumo, impossibilitado de se abastecer nos únicos mercados fornecedores de então, estimularam o nascimento de uma multiplicidade de pequenas indústrias, que se desenvolveram principalmente em São Paulo" (SIMONSEN, 1973, p. 20).

Simonsen agregava aos dados censitários estimativas sobre a produção industrial a partir de 1914; seus resultados mostravam que a produção para 0 ano 
de 1919, em termos reais, era mais do que o dobro da produção de 1914, tanto para São Paulo quanto para o conjunto da indústria brasileira. Embora não formulasse qualquer proposição geral sobre a relação entre a crise do setor externo e a industrialização, Simonsen apresentava dados que corroboravam a noção de que na crise da Primeira Guerra Mundial a indústria tivera "novo e decisivo impulso".

Talvez tenha sido Warren Dean o primeiro autor a formular uma crítica elaborada à proposição de que a indústria brasileira crescera substancialmente durante a Primeira Guerra Mundial, e, mais do que isso, que fosse nas crises do setor externo que a indústria alcançasse melhores condições de expansão (DEAN, 1971).

A tese de Dean, sintetizada no título do primeiro capítulo de sua obra $O$ Comércio do Café gera a Indústria, apontava no sentido contrário ao sugerido pela "Teoria dos Choques Adversos". Para Dean, a expansāo das exportaçōes de café criava tanto o mercado consumidor quanto as condições para o estabelecimento de indústrias no país (capitais, importação de equipamentos a baixos preços, oferta de mão-de-obra, crédito no exterior, etc). Na defesa de sua tese, Dean indicava dois tipos de crítica aos defensores dos choques adversos.

Por um lado, fazia restriçōes aos dados apresentados por Simonsen no sentido de afirmar o crescimento industrial durante a Primeira Guerra Mundial, seja por ter tomado 1914 como base - apesar de ter sido ano de fraco desempenho industrial -, seja pelos índices de preços utilizados para deflacionar as séries nominais de produção industrial. Dean conclui que a Primeira Guerra não foi, por si mesma, estimulante para a indústria paulista - contrariamente ao que afirmava Simonsen - e que parte dos influxos positivos adveio do aumento de exportações de manufaturados (como carne congelada, açúcar refinado e tecidos de algodāo) (DEAN, 1971 p. 104-7)². Dean também nāo aceita 0 argumento usual de que o declínio cambial nas fases de crise pudesse proteger a indústria nacional: isso porque na crise a demanda deve declinar por causa da retração da renda interna subseqüente à queda das exportações e também porque as importaçōes de matérias-primas, máquinas e matérias auxiliares se tornavam mais caras, bloqueando, por esse lado, o crescimento da indústria.

Tudo isso conduzia Dean a afirmar que "durante os anos em que o café se vendeu bem, tudo faz crer que a indústria foi mais lucrativa e se expandiu mais depressa"; "Durante os anos maus do comércio do café... a indústria local agonizou" (DEAN, 1971, p. 93-4).

A partir dessas conclusōes, Dean indaga por que generalizadamente se admite que a Primeira Guerra Mundial foi estimulante para a indústria brasileira. E sugere, em seguida, sua resposta:

"Quanto à tendência de observadores mais recentes para aceitar os relatos contemporâneos pelo seu valor nominal, pode-se sugerir que uma teoria que associa o crescimento ao colapso do comércio agrada aos sentimentos nacionalistas, pois implica que as fontes estrangeiras de suprimentos não são merecedoras de confiança e que a produ-

2 Os dados de Dean foram cuidadosamente discutidos por Cano, Rafzes da concentraçāo industrial em Säo Paulo, 1977, p. 154-74. 
cão nacional é capaz de aceitar qualquer desafio. Além disso, uma teoria ässim $e$ útil aos intelectuais e burocratas brasileiros urbanos por demonstrar às elites econômicas recalcitrantes a inevitabilidade da industrialização. Os escritos de Celso Furtado, por exemplo, estão prenhes dessa mensagem. Os estrangeiros, por outro lado, folgam de presumir que a industrialização de uma área dependente como o Brasil foi um produto de circunstância, fenômeno temporário que poderia ser invertido pela paz entre as naçōes industriais e o encorajamento do comércio livre" (id., ibid., p. 108) 3

Estavam definidas, desse modo, as duas grandes linhas interpretativas da industrializaçāo na Primeira República: a "Teoria dos Choques Adversos" e a tese da "industrialização induzida pelas exportaçōes". A continuidade da polêmica tendeu a privilegiar a discussāo mais minuciosa dos mecanismos econômicos de crescimento industrial, não explicitando as divergências ideológicas embutidas na controvérsia. Vejamos alguns momentos dessa polêmica que ocupa a maior parte da década dos 70.

Villela e Suzigan (1973, p. 145-50) questionaram o impacto positivo da Primeira Guerra Mundial sobre a indústria com base em dados estatísticos. Ao verificarem o declínio das importaçōes de matérias-primas, matérias auxiliares e bens de capital no período 1914-1918 (comparado ao período 1911-1913), os autores colocam em dúvida a possibilidade de ter ocorrido durante a guerra um surto de industrialização. Os indicadores do produto industrial, construídos pelos autores (abrangendo os ramos têxtil, de fumo, bebidas e vestuário, responsáveis por $50 \%$ do valor adicionado em 1919) mostravam oscilaçōes no período, sem uma tendência marcante de crescimento. Admitiam apenas que certos produtos industriais ou semi-industriais foram contemplados com aumento da demanda externa (e não da demanda interna como seria de prever nos termos dos choques adversos).

A esse conjunto de dados, agregavam a informaçāo de que os indicadores de formação de capital pela indústria mostravam forte crescimento durante 0 periodo 1905-1912, o que os levava a concluir:

"Finalmente, talvez o correto seja indagar se o surto industrial que parece ter ocorrido nos anos 1905-1912 não teria levado a um processo de industrialização na ausência da guerra de 1914-1918" (VILLELA e SUZIGAN, 1973, p. 150).

Estavam definidas, desse modo, as duas linhas interpretativas da industrialização na

Primeira República: a

"Teoria dos Choques

Adversos" e a tese da

"industrialização induzida pelas exportaçöes".
Tendo por base diferentes fontes de dados, Albert Fishlow (1972) acabava por endossar a "Teoria dos Choques Adversos", se bem que com algumas qualificaçōes. Isto não quer dizer que ele refute a tese da "industrializaçāo induzida pela expansāo das exportaçōes". Vejamos alguns momentos de sua análise da industrialização brasileira.

Entende Fishlow que um primeiro surto de substituição de importaçōes ocorre na céćcada de 1890, "como uma conseqüência direta das finanças infla-

3 Ccnvém ressaltar que Celso Furtado, ao discutir a indústria latino-americana ate 1930, nảo atribui qualquer papel à Primeira Guerra Mundial. Pelo contrário, caracteriza esse perfodo como de "Industrializaçăo induzida pela expanssăo das exportaçōes". Ver Furtado, Formaçáo económica da América Latina, 1970, cap. X X XI. 
cionárias, não tendo sido influenciado por proteção tarifária”'. Em particular, de 1895 a 1899, há declínio da importação de tecidos, concomitantemente ao aumento da produçāo interna de tecidós. Embora a expansão de crédito dos anos iniciais da República tenha constituído estímulo à iniciativa empresarial nacional, o autor entende que a principal razão para a "substituição de importaçōes" no período está nas relaçōes, defasadas e ampliadas, entre a taxa de câmbio e a inflação interna gerada pelo grande aumento na oferta monetária. Tal defasagem parece ter favorecido, num primeiro momento, as importações em geral de tecidos, mas também de bens de capital -, para, a seguir, por meio de desvalorização real do câmbio, estimular as compras internas de bens de consumo. Portanto, este primeiro surto de substituiçāo de importações se devia principalmente ao mecanismo cambial, embora este não fosse determinado propriamente por uma crise externa.

Fishlow reconhece também que o período 1905-1913 registra acelerado crescimento da produção industrial têxtil, embora esta não se tenha feito às custas das importaçōes. Diz o autor:

“... a explicaçāo mais plausível parece ser o aumento da demanda associado aos aumentos na renda. A recuperação dos preços do café e da renda do setor cafeeiro, provavelmente desempenha um papel significante a partir de 1905 . A demanda por produtos têxteis e, mais genericamente, por produtos industriais, estava provavelmente intimamente relacionada ao destino do setor cafeeiro, assim como a própria taxa de crescimento industrial" (FISHLOW. 1972).

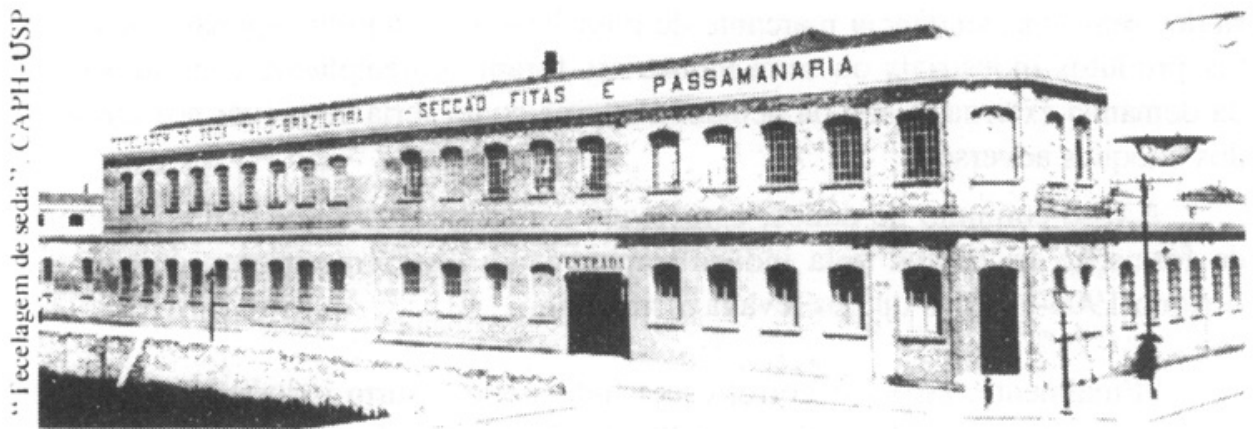

Percebe-se, pois, que a tese da industrialização induzida pelas exportações está presente na compreensão do crescimento industrial do período 1905-1913. Cabe indagar como se observa a indústria durante a Primeira Guerra Mundial.

Fishlow mostra que houve crescimento da produçāo industrial e que este crescimento se deveu, pelo menos no setor têxtil, quase inteiramente à substituição de importaçōes. Portanto, nāo foi apenas a demanda externa que, durante a guerra, estimulou a produção industrial. Além disso, entende que os autores preocupados em mostrar o reduzido nível de investimentos entre 1914 e 1918 ignoram o papel que os lucros acumulados durante a guerra podem ter representado para a formação de capital após o fim do conflito. Em suma:

" $O$ choque exógeno causado pela guerra permitiu que o excesso de capacidade anterior fosse utilizado, e levou o processo de industria- 
lização um passo adiante, até o ponto de substituição de importaçōes

que até então continuavam a competir" (FISHLOW, 1972, p. 20).

Ou seja, se para o período 1905-1913, a industrialização (ou mais precisamente $o$ crescimento industrial) era induzida pelas exportações, durante a Primeira Guerra Mundial surgia como fruto de um choque adverso.

Percebe-se, desse modo, que as explicações do crescimento industrial na Primeira República, que se pautavam por uma das duas teses aqui expostas choques adversos ou indução pelas exportações -, mostravam-se incapazes de dar conta dos diferentes momentos desse processo. As tentativas feitas no sentido de avaliar a adequação de uma ou outra tese acabavam caindo em impasse insolúvel. As conclusōes de Flávio e Maria Teresa Versiani, em artigo originalmente publicado em 1975 (VERSIANI e VERSIANI, 1977, p. 121-142) são exemplares desse impasse. Ao estudar a evolução da indústria têxtil brasileira, os autores mostram, por exemplo, que os periodos caracterizados por desvalorização da moeda nacional corresponderam a fases de crescimento da produção; por outro lado, períodos de intensificação do investimento coincidiram com fases de câmbio relativamente alto. Desse modo, a crise externa, que conduz à queda do câmbio, tinha efeito positivo sobre a produção industrial e negativo sobre o investimento. A expansão das exportações, ao contrário, elevando o câmbio, favorecia o investimento mas limitava o crescimento das exportaçōes pelo barateamento relativo dos importados. Este caráter ambíguo da relaçāo entre exportaçōes e indústria é explorado ao longo do texto e conduz à seguinte conclusão:
"Nas interpretaçōes da industrialização brasileira costumam se dis- tinguir esquematicamente duas posiçōes opostas, no que toca à reia- ção entre atividade exportadora e produção interna de manufaturas: a da 'teoria dos choques adversos' - que associaria o crescimento da indústria com as fases de crise na atividade exportadora - e a da 'complementaridade', que vê a industrialização como basicamente promovida pelo crescimento das exportações. À luz de nossos argu- mentos acima, ambas as colocaçōes parecem incompletas: 0 início da industrialização surge como resultado dos estímulos produzidos pela conjugação de períodos de dificuldades no setor externo com perío- dos em que a economia voltou-se mais para o exterior. De um lado, evidencia-se o fato de que os 'choques adversos' não teriam tido o impacto que tiveram, na ausência de fases anteriores de formação de capacidade produtiva. De outro lado, a interpretáção da indus- trialização como um resultado direto da expansão das exportaçōes aparece como notoriamente insuficiente e simplista" (VERSIANI e VERSIANI, 1977, p. 141).

Percebe-se claramente, portanto, que em meados dos anos 70 a polêmica central sobre a industrialização na Primeira República encontrava-se esgotada. "Choques adversos" e "industrialização induzida pelas exportaçōes" não poderiam mais ser defendidas como explicaçōes gerais para o processo de industrialização. Os mecanismos descritos por tais explicaçōes são encontrados em um ou outro momento da industrialização na Primeira República, não sendo, no entanto, mutuamente exclusivos. 


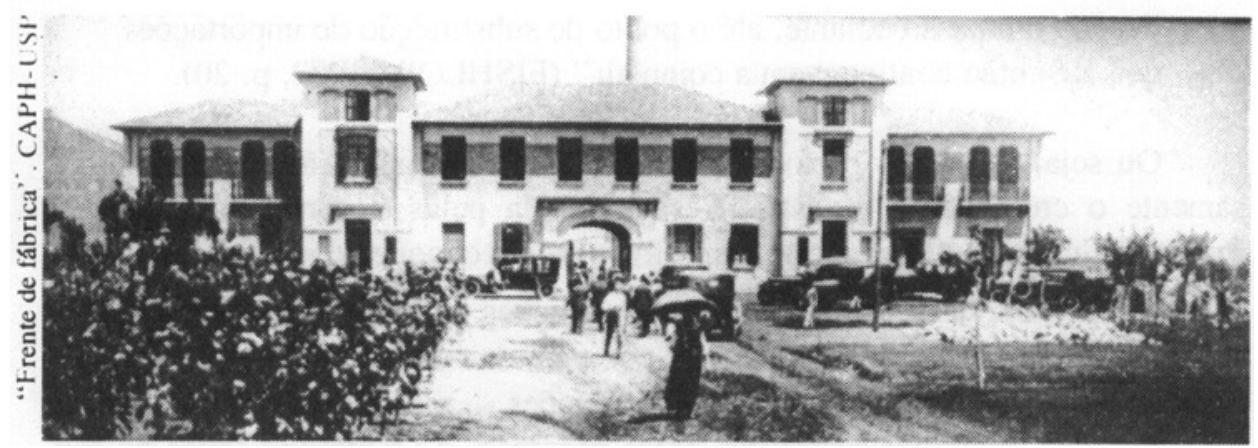

Evidentemente, a superação desse impasse pressupunha 0 abandono da problemática herdada do pensamento da CEPAL, qual seja, a de identificar o momento e a forma da ruptura do caráter agroexportador das economias latinoamericanas. Era preciso, portanto, instaurar uma nova problemática dentro da qual fosse incluída a questão do desenvolvimento da indústria.

\section{A Indústria na Primeira República e o Desenvolvimento do Capitalismo no Brasil}

A problemática do desenvolvimento do capitalismo no Brasil não é nova; talviez sua origem possa ser buscada em debates políticos travados ainda na Primeira República. Neste texto, no entanto, pretendemos apenas registrar dois momentos recentes dessa problemática, exatamente porque ar é central o tema da industrialização.

Ao longo dos anos 60 , vários trabalhos produzidos pelo núcleo de pesquisas de sociologia da Faculdade de Filosofia, Ciências e Letras da Universidade de Sāo Paulo já estabeleciam relações entre industrialização e desenvolvimento do capitalismo. Em linhas gerais, no entanto, aceitavam as interpretaçōes econômicas identificadas com a "Teoria dos Choques Adversos", propondo, no entanto, a adoção de perspectiva mais abrangente. Um desses estudos, talvez 0 primeiro, é o artigo de Fernando Henrique Cardoso (1960), "Condiçōes sociais da industrialização: o caso de São Paulo". O próprio autor definia sua forma de inserção nas explicações sobre o crescimento da indústria brasileira:

"O esquema usualmente utilizado para a explicação do crescimento industrial do Brasil, e de São Paulo, leva em consideração apenas as condiçōes econômicas e naturais exigidas pela industrialização. Omite, pois, as condiçōes sociais que a permitiram. Descreve-se o processo de industrialização como se fosse possível criá-lo integralmente todas as vezes que determinadas condiçōes econômicas o propiciassem. (...) Dito noutras palavras: todas as vezes que havia uma interrupção no fluxo para o exterior da renda gerada pelo setor de exportação da economia, criavam-se estímulos para a aplicação desta renda no País. Por isto, as guerras mundiais são geralmente apontadas como as causas da industrializaçāo do Brasil, uma vez que no seu decurso não havia possibilidade de consumir a renda gerada pela economia exportadora do País através da importação de produtos industriais, cujo consumo, ao mesmo tempo, continuava a ser requerido" (CARDOSO, 1960, p. 32). 
O autor não contestava o valor dessa explicação, apenas a considerava parcial por omitir as condiçōes sociais que constituíam pré-requisito para a industrialização. Ou seja,

“... o processo de industrialização em qualquer região supõe, como pré-requisito, a existência de certo grau de desenvolvimento capitalista, e, mais especificamente, supōe a préexistência de uma economia mercantil e, correlatamente, implica num grau relativamente desenvolvido da divisāo social do trabalho" (id., ibid., p. 33).

Tais pré-requisitos, no entanto, devem estar instalados antes que se estabeleça a produção propriamente industrial. Isto teria ocorrido no bojo da expansão cafeeira em direção ao oeste paulista em que, pela crescente escassez e progressiva elevação do preço do escravo, o fazendeiro passou a importar mãode-obra livre. Assim, "perdia sua condição de senhor, para tornar-se um empresário capitalista". Simultaneamente, é claro, formava-se um mercado de trabalho com base nos imigrantes europeus que, chegando ao Brasil já "destituídos" da posse de meios de produção, deviam oferecer sua força de trabalho em troca de salários. Este é o ponto de partida ao qual se acrescentam outros elementos: diversificação do emprego do capital (estradas de ferro, comércio, bancos), desenvolvimento de núcleos urbanos, em suma, intensificação da divisão social do trabalho e generalização de relaçōes mercantis. Estas são, em síntese, as condições sociais da industrialização, seus pré-requisitos. O crescimento industrial se verificaria, então, nos momentos de ruptura das relaçōes com o mercado mundial, como as guerras e as grandes crises econômicas.

Percebe-se, portanto, de que modo a problemática do desenvolvimento do capitalismo no Brasil se articulava com as interpretações do crescimento industrial decorrente das crises do setor externo da economia brasileira ${ }^{4}$.

Em estudo sobre o Conde Matarazzo, José de Souza Martins, também da Faculdade de Filosofia da USP, apresentava elementos interpretativos que escapavam ao esquema dos choques adversos. Por um lado, entendia o autor que a indústria que surge em São Paulo nas últimas décadas do século XIX não tinha o caráter de substituiçāo de importaçōes; ela explorava as possibilidades manufatureiras surgidas nas "franjas da economia exportadora" (MARTINS, 1973, p. 71). Trata-se de conjunto de mercadorias cujo consumo está associado à introdução dos imigrantes europeus em São Paulo, mercadorias essas que dificilmente poderiam ser importadas (caso, por exemplo, da banha e da cerveja).

A problemática do desenvolvimento do capitalismo no Brasil não é nova; talvez sua origem possa ser buscada em debates polfticos travados ainda na Primeira República.

A estes primeiros passos da indústria (de início em pequenos estabelecimentos, nos anos 90 do século passado já em empresas de maior dimensão), segue-se outra fase em que se observa a substituiçāo de importaçōes. $O$ desequilibrio externo da economia brasileira obriga, na virada do século, à adoção de medidas desestimuladoras de importaçōes. Em consequiência, reduzia-se a arrecadação da principal fonte tributária (as tarifas alfandegárias). Simultaneamente, e não por mera coincidência, instituía-se o imposto de consumo, reconhecimento de que a renda nāo era mais apenas gasta com importações, mas também

4 Uma síntese precisa do estado da questão nos nıeados da década de 60 é apresentada em Cohn, "Problemas da industrialização ne século XX", 1969, p. 285-318. 
(e em escala apreciável) com produtos internos. Conclui, entāo, Martins (1973, p. 74-5):

"Nāo sendo um governo protecionista, mas sim liberal, valia-se da indústria existente para resolver os problemas da sociedade exportadora e, ao mesmo tempo, eliminava as eventuais proteçōes, expondo-a à concorrência de fato com o produto estrangeiro e taxando o seu produto. (...) Talvez a característica mais importante desses eventos esteja no fato de terem ocorrido num governo identificado profundamente com as atividades de exportação, supostamente incompatíveis e antagônicas à industrializaçāo. $O$ exposto deixa nítido que a questão não se propunha assim. $O$ que importava, sobretudo, era a racionalidade da sociedade agroexportadora e que essa seria a porta viável à entrada do industrialismo".

Percebe-se, portanto, que a substituiçāo de importaçōes - embora não se tzate propriamente do que se convencionou chamar de processo de substituição de importações - podia ocorrer no interior da economia agroexportadora, sem que isto representasse uma ruptura do caráter dessa economia. Também não se trata, claramente, da tese da industrialização induzida pelas exportações, na forma como usualmente foi formulada. Trata-se, isto sim, de reconhecer que os desequilíbrios (talvez pudéssemos dizer as contradiçōes) da economia exportadora passam a exigir o desenvolvimento de algum tipo de indústria interna.

Nesta linha de argumentação, duas obras de meados dos anos 70 consolidam o entendimento do crescimento industrial como parte do processo de desenvolvimento do capitalismo no Brasil, ao mesmo tempo que propunham uma "solução" para o impasse entre "Teoria dos Choques Adversos" e "industrializaçāo liderada pelas exportaçōes": Expansão Cafeeira e Origens da Indústria no Brasil, de Sérgio Silva (1976) - texto original de 1973 -, e $O$ Capitalismo Tardio, de João Manuel Cardoso de Mello (1986) - texto original de 1975. O ponto de partida de ambos é o exposto anteriormente com base em Fernando Henrique Cardoso: para compreender a gênese da indústria é preciso buscar suas pré-condiçōes no desenvolvimento capitalista da economia cafeeira. Imigração européia, trabalho assalariado, formação de mercado de trabalho, constituição da burguesia cafeeira que é dominantemente mercantil, são elementos comuns às análises dos dois autores no esforço de caracterizar as especificidades do desenvolvimento capitalista no Brasil. De maior interesse para nós, neste momento, é observar como são tratadas as relaçōes entre café (exportaçāo) e indústria nessas duas obras.

Sérgio Silva, após examinar a questão, conclui que:

“... as relações entre o comércio exterior e a economia cafeeira, de um lado, e a indústria nascente, de outro, implicam, ao mesmo tempo, a unidade e a contradição. A unidade está no fato de que o desenvolvimento capitalista baseado na expansão cafeeira provoca o nascimento e um certo desenvolvimento da indústria; a contradiçāo, nos limites impostos ao desenvolvimento da indústria pela própria posição dominảnte da economia cafeeira na acumulação de capital" (SILVA, 1976, p. 103).
Ao longo dos anos 60, vários trabalhos produzidos pelo núcleo de pesquisas de sociologia da Faculdade de Filosofia, Ciências e Letras da

Universidade de Sāo Paulo já estabeleciam relaçōes entre industrialização e desenvolvimento do capitalismo. 


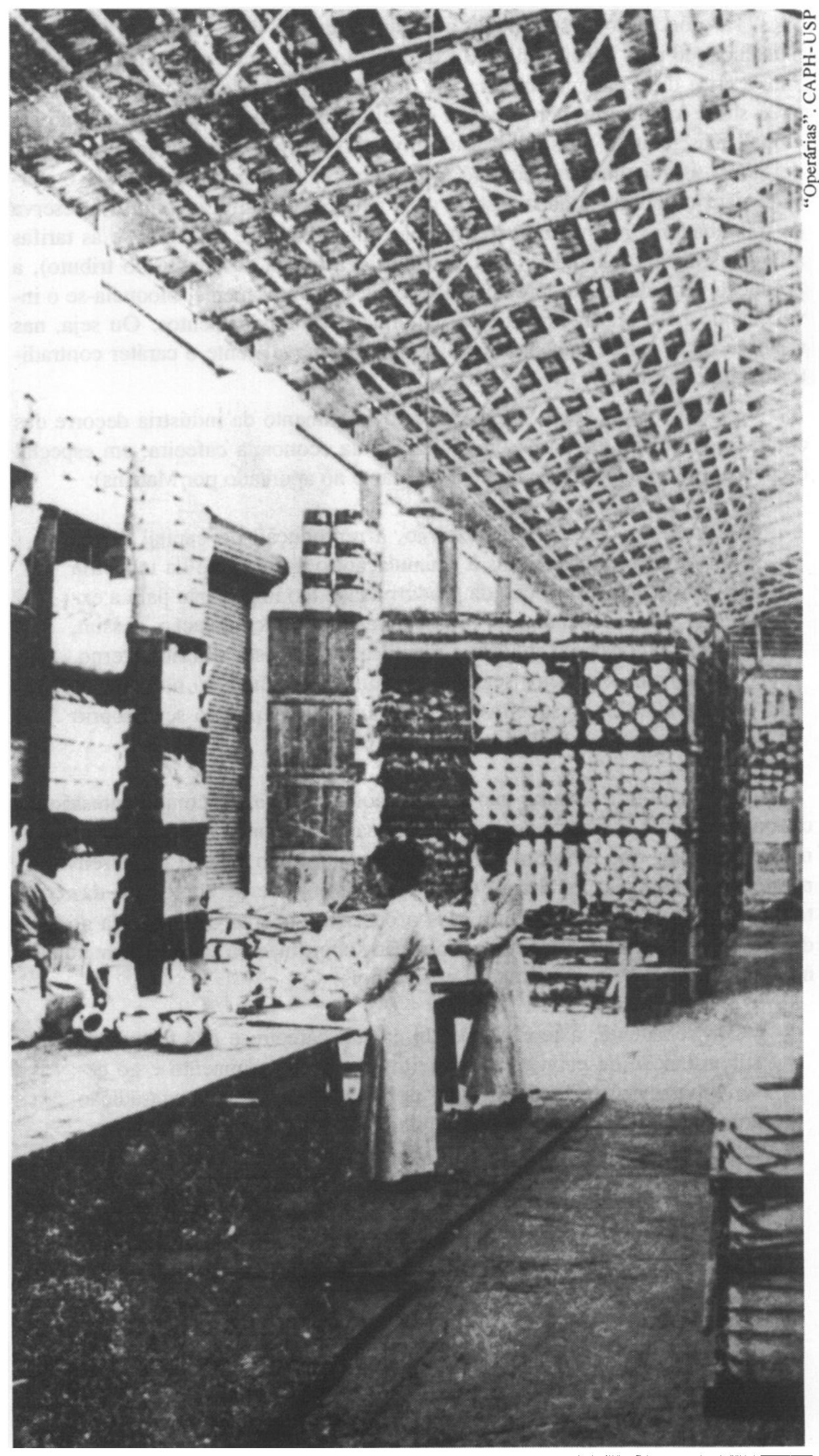


Tal conclusão é sustentada a partir da crítica das teses que admitem a existência de uma relação unívoca (direta ou inversa) entre café e indústria. Assim, a crise da economia cafeeira tem, a um só tempo, efeitos positivos e negativos sobre a indústria; por provocar o declínio cambial, protege a produção nacional, mas reduz a possibilidade de investimento pelo encarecimento dos importados; se trabalhadores do café são desempregados na crise, reduz-se o mercado para os produtos da indústria, mas, pelo êxodo rural, amplia-se a reserva de trabalhadores para a indústria no mercado urbano de trabalho; se as tarifas alfandegárias são elevadas (para compensar a queda da receita do tributo), a produção nacional ganha proteção adicional, mas, novamente, bloqueia-se o investimento pelo encarecimento da importação de equipamentos. Ou seja, nas relaçōes entre café e indústria manifesta-se invariavelmente o caráter contraditório aqui exposto.

Por outro lado, para Sérgio Silva, o nascimento da indústria decorre das contradições inerentes ao desenvolvimento da economia cafeeira, em especial do desequilibrio externo (de modo semelhante ao apontado por Martins):

\begin{abstract}
"Através do desequilíbrio externo, a reprodução do capital impōe transformaçōes necessárias à acumulação: o nascimento da indústria e a conseqüente elevaçāo da produtividade tāo importante para a expansāo do excedente e o prosseguimento da acumulação. Assim, através da constante solução e recolocação do desequilíbrio externo, o capitalismo brasileiro segue seu caminho, escondendo no palheiro das atribulaçōes financeiras a contradição que explica o seu próprio desenvolvimento"' (SILVA, 1976, p. 109).
\end{abstract}

O desequilíbrio externo não aparece aqui, no entanto, como expressão de choques adversos e sim da posição subordinada da economia brasileira na economia mundial, que define a economia cafeeira como núcleo do desenvolvimento do capitalismo no Brasil, e o desequilibrio externo como uma das contradições desse desenvolvimento. Mas o desenvolvimento da indústria no seio da economia cafeeira - portanto, em posição subordinada à economia mundial não implica ruptura com a situação prévia, pois:

"Concretamente, a reprodução do capital cafeeiro e das formas de subordinação da economia brasileira levam ao nascimento e ao desenvolvimento da indústria que, por sua vez, está em contradição com a própria reproduçāo do capital cafeeiro e as formas de subordinação da economia brasileira. Mais uma vez afastamos a noção simplista de contradiçāo, segundo a qual as contradições internas do capitalismo lovariam à sua própria destruição. Nem a subordinação do Brasil na economia mundial e o capital cafeeiro excluem a industrialização, nem a industrialização implica na destruição dos laços que unem o Brasil à economia mundial e muito menos ainda na destruição do capitalismo no Brasil. A industrialização pode, simplesmente, levar a mudanças nas formas de subordinação associadas a transformaçōes do capitalismo no Brasil: por exemplo, a perda da posição dominante por parte do capital cafeeiro ou mesmo do capital comercial em geral"' (SILVA, 1976, p. 112-13).
Na década de 1980, reduziu-se a intensidade do debate sobre a industrialização na Primeira República, pelo menos nos moldes em que se colocou ao longo dos anos 70. 
Percebe-se, desse modo, que economia mundial, economia cafeeira e indústria são integradas na análise, sendo importante reter neste momento a proposição de que a industrialização pode conduzir à perda da posição dominante do capital cafeeiro.

Embora Cardoso de Mello parta dos mesmos pressupostos - economia cafeeira cria as precondições para o nascimento do capital industrial e as relaçōes entre café e indústria sāo contraditórias - sua análise indica algumas diferenças em relação à de Sérgio Silva. Por um lado, não aprofunda a relação com a economia mundial, apesar de considerar os fatores externos o determinante em última instância do movimento da economia brasileira à época; por outro lado, ao delinear um modelo de ciclo conjunto do capital cafeeiro e do capital industrial, sugere dinâmica diversa da indicada em Sérgio Silva.

Em relação ao primeiro ponto Cardoso de Mello admite que:

"A posição subordinada da economia brasileira na economia mundial capitalista está duplamente determinada: pelo lado da realização do capital cafeeiro e pelo lado da acumulação do capital industrial. Esta dependência resulta, na verdade, da não constituição de forças produtivas capitalistas, isto é, do bloqueio da industrialização (que se expressa internamente na hegemonia do capital cafeeiro, que é dominantemente mercantil, sobre o capital industrial). Por outro lado, a fragilidade do capitalismo brasileiro transformou-nos em campo de exportaçāo de capitais dos países capitalistas maduros, ao criar, näo obstante, oportunidades de inversão ao capital estrangeiro: quer ao capital de empréstimo, de forma predominante, quer ao capital de risco, que se dirige basicamente aos setores de infra-estrutura, comercial e financeiro, mas, também, ao setor industrial" (MELLO, 1986, p. 108-9).

Aparentemente, aqui, a subordinação da economia brasileira à economia mundial capitalista poderia ser rompida pela "constituiçāo de forças produtivas capitalistas", embora deva-se considerar o fato de haver crescente inversäo de capital estrangeiro no País. De qualquer modo, a questão da subordinação à economia mundial capitalista aparece aqui com menos força do que em Sérgio Silva.

No modelo de ciclo conjunto do capital cafeeiro e do capital industrial também surgem diferenças entre as interpretaçōes de Sérgio Silva e J.M. Cardoso de Mello: no primeiro, o desequilibrio externo aparece com papel decisivo no nascimento da indústria; no segundo, pode ser identificado como um momento do ciclo referido.

Neste ciclo, o ponto de partida escolhido é a expansão da economia cafeeira: o crescimento dos preços eleva a taxa de acumulação financeira mais rapi-

A pesquisa mais cuidada mostrou, no entanto, que os anos 20 registraram grande dinamismo e diversificação da produção industrial. damente do que a real, na atividade cafeeira, permitindo a transferência de capitais pára a indústria (mesmo que as margens de lucro na indústria sejam inferiores à do café). Em seguida, a taxa de acumulação real cafeeira se acelera, buscando atrair recursos externos, impondo, por isso, maior concorrência externa à indústria instalada. Esta, por sua vez, se defende por meio de concentráçāo e centralização de capitais: 


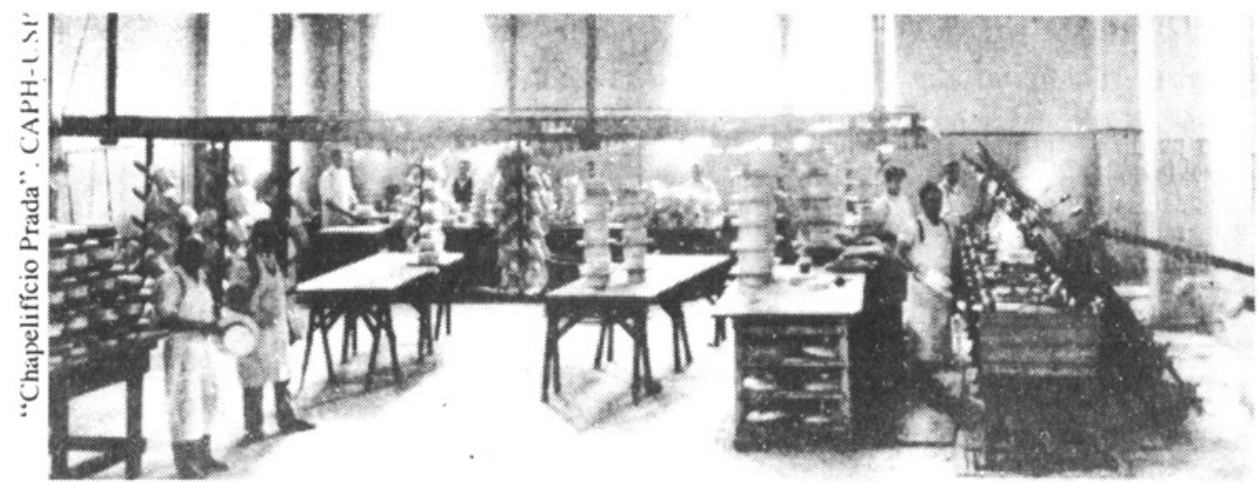

Iniciada a reversão do ciclo dos preços do café - conseqüente à superacumulação -, eleva-se a rentabilidade da indústria em relação ao café, o que ajuda a manter por algum tempo a taxa de acumulação da economia. Deflagrada a crise cafeeira, café e indústria são arrastados por ela. Mas a indústria ainda pode se defender pois a reduçāo da capacidade de importar reserva algum mercado à indústria que inicia sua recuperação pela utilização da capacıdade ocısa. Este, em breve síntese, é o ciclo referido e que mostra os diferentes momentos de articulação entre capital cafeeiro e capital industrial (MELLO, 1986, p. 106-8).

Apesar das diferenças indicadas, as teses de Sérgio Silva e Cardoso de Mello sugerem alternativas que superam o impasse em que se situava a polêmica entre "Teoria dos Choques Adversos" e "industrialização induzida pelas exportaçōes". Certamente, a discussāo da indústria na Primeira República não retornará àquela polêmica que a dominou por muito tempo. É certo também que há outras tendências de análise que não incorporam a ótica da industrialização como parte do processo de desenvolvimento do capitalismo no Brasil; assim como há alguns temas igualmente polêmicos e relevantes que não estão resolvidos dentro dessa corrente. Tentamos, a seguir, explorar alguns destes aspectos da industrialização na Primeira República.

\section{A Industrialização na Primeira República: alguns temas ainda em discus- são}

$\mathrm{Na}$ década de 1980, reduziu-se a intensidade do debate sobre a industrializaçāo na Primeira República, pelo menos nos moldes em que se colocou ao longo dos anos 70. Uma das poucas obras recentes sobre o tema - a já citada Induistria Brasileira, de Wilson Suzigan - a par de importante contribuição empírica, propōe uma interpretação alternativa, baseada na "teoria do crescimento econômico induzido por produtos básicos" ou na "abordagem dos linkages generalizados ao desenvolvimento" (SUZIGAN, 1986, p. 66-72). Apesar disso, não se reacende uma polêmica sobre os processos mais gerais que conduziram à industrializaçāo no Brasil. Permanecem, no entanto, alguns temas menos abrangentes, mas relevantes para a compreensão do conjunto do processo. Veremos, a seguir, alguns destes temas.

\section{O significado dos anos 20 para a indústria no Brasil}

Foi usual considerar os anos 20 deste século como uma década desfavorável à indústria instalada no Brasil. Tal conclusão era alcançada com base na 
experiência da indústria têxtil e podia ser justificada pela manutenção de elevadas (ou ao menos estáveis) taxas de câmbio durante grande parte da década. $\mathrm{A}$ pesquisa mais cuidada mostrou, no entanto, que os anos 20 registraram grande dinamismo e diversificação da produção industrial. É significativa a coincidência da opinião de vários autores em relação a este fato.

Wilson Cano, embora reconheça a existência de algumas dificuldades para a produção têxtil, mostra que a expansão da indústria se verifica, principalmente em São Paulo e em contexto de concentração de capitais. Assim, entre 1918 e 1928, a produção industrial de São Paulo mais do que duplicara - quase triplicando quando se exclui a produção de tecidos de algodão (CANO, 1973, p. 185).

Wilson Suzigan também entende ser a década de 20 distinta da fase anterior da indústria brasileira. Antes da Primeira Guerra Mundial, tanto o mercado para os produtos industrializados quanto os investimentos industriais seriam induzidos pelo setor exportador. Após a Primeira Guerra - e em especial ao longo dos anos 20 - reduz-se progressivamente esta dependência da indústria em relação ao setor exportador pelo surgimento de uma demanda interna de insumos, matérias-primas, etc., cuja contrapartida é o padrão nais complexo de desenvolvimento industrial. Suzigan afirma, por fim, que após 1930 tanto o mercado para a indústria deixa de depender do setor industrial, quanto o investimento industrial deixa de ser induzido pelas exportaçōes (embora ainda dependa da capacidade de importar gerada por elas) (SUZIGAN, 1986, p. 345-52).

Conclusão semelhante é apresentada por Flávio Versiani, após o exame de índices da produção industrial nos anos 20:

“A expansão e a transformação da estrutura produtiva na indústria brasileira parece ter sido um processo mais gradual do que freqüentemente se supōe. A década de 1930 não significa, pois, uma ruptura profunda corr o passado (como parte da literatura da CEPAL sugere). A Depressão foi importante em grande parte por causa do que ocorrera nas décadas anteriores" (VERSIANI, 1982, p. 22).

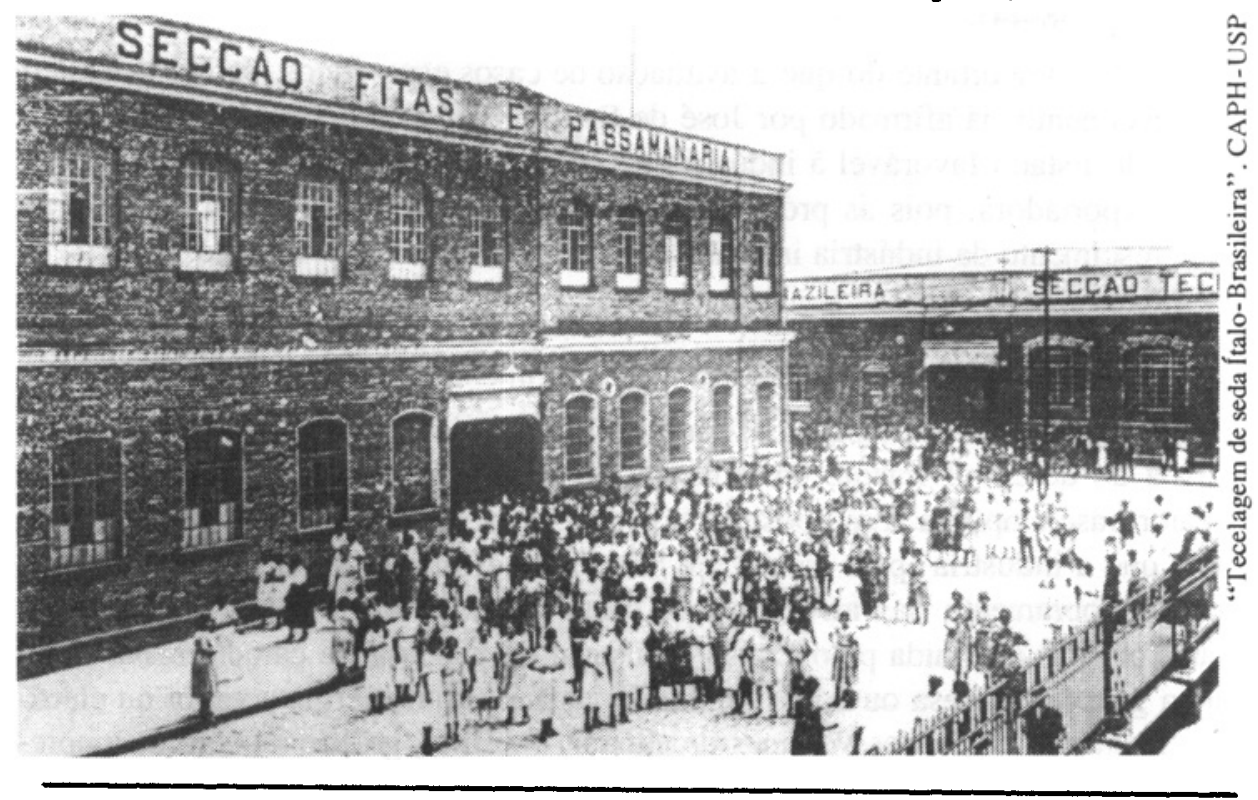


Evidencia-se, desse modo, a tendência a não mais se fixar apenas na discussão da relação entre crise (ou expansão) das exportaçōes e indústria. Embora se reconheça os anos 30 como momento de transformaçōes importantes, tal resultado não é reconhecido apenas como fruto da crise externa, e sim de um longo processo de crescimento industrial. Já vimos como Suzigan caracteriza a mudança dos anos 30; Cardoso de Mello afirma que, após 1933, a "acumulação se mcve de acordo com um novo padrão" em que a expansão industrial é a base sobre a qual se assenta a acumulação (embora se trate de industrialização restringida porque ainda não foi implantado o núcleo fundamental da indústria de bens de produção); Sérgio Silva caracteriza generiçmente (não especificando os anos 30 como o momento em que ocorre) a perda da posição dominante por parte do capital cafeeiro para o capital industrial. Em todos esses exemplos está presente, apesar das diferenças analíticas que os separam, uma visão semelhante do processo de industrialização: este não é o fruto de "choques externos", nem o simples resultado linear do crescimento da produção industrial. Esse processo se traduz em relações complexas entre indústria, exportações e economia mundial que, em determinados momentos, passam por mudanças qualitativas fundamentais.

\section{Estado, tarifas e industrializaçāo na Primeira República}

Usualmente atribui-se ao Estado brasileiro na Primeira República o caráter de representante dos interesses cafeeiros. Conseqüentemente, afirma-se que sua política econômica deveria ser não-industrializante ou mesmo antiindustrialista. O estudo empírico da política tarifária e dos efeitos protecionistas das flutuações cambiais levou alguns autores a matizar essa afirmação. Obviamente, não se trata de afirmar, ao contrário, que o Estado na Primeira República teve qualquer tipo de ação industrializante, mas simplesmente de reconhecer que certos instrumentos de política econômica podem ter favorecido, em determinadas circunstâncias, a indústria em geral ou setores específicos. Nícia Vilela Luz (1975) e Flávio e Maria Teresa Versiani (1977) foram autores que procuraram explorar essa temática, cujo balanço foi adequadamente feito por Suzigan (1986, p. 38-44).

Mais importante do que a avaliaçāo de casos específicos, parece-nos o reconhecimento, já afirmado por José de Souza Martins e Sérgio Silva, de que a ação do Estado favorável à indústria não é contrária à racionalidade da economia exportadora, pois as próprias contradiçōes desta podem exigir algum grau de crescimento da indústria interna como recurso para a acumulação.

\section{A gênese da indústria: grande empresa ou pequena escala de produção?}

A seqüência Artesanato-Mrnufatura-Indústria foi, algumas vezes, associada ao desenvolvimento da indústria no Brasil, embora isso fosse feito sem maior base empírica. Em oposição a essa tese, alguns estudos procuraram mostrar que a indústria (pelo menos em São Paulo) originou-se, em grande medida, do desdobramento das atividades de casas importadoras e que a indústria em suas origens (definida pelo Censo Industrial de 1907) já se caracterizava como uma grande empresa ou como grande indústria - com energia a vapor ou elétrica, máquinas e grandes volumes de capital, portanto, grande número de empre-
... a ação do Estado favorável a indústria nâo é contrária à racionalidade da economia exportadora, pois as proprias contradiçōes desta podem exigir algum grau de crescimento da indústria interna como recurso para a acumulação. 
gados. Estas teses estāo explicitadas, por exemplo, nos trabalhos de Warren Dean (1971, cap. 2) e de Sérgio Silva (1976, cap. 4).

José de Souza Martins, a partir de alguns elementos empíricos, sugeriu que, em São Paulo, antes mesmo da introdução de imigrantes, já havia uma produção artesanal espalhada em vários municípios (e não só na capital):

“Há várias indicaçōes de que antes da abolição do escravismo e da chamada grande imigração (1886/88) ocorreu uma significativa expansão da atividade comercial e da indústria em pequena escala na província de S. Paulo; não apenas na capital, mas em quase todas as cidades dc interior. Isso parece sugerir que nessa época a indústria artesanal passou a desenvolver-se mais intensamente nos meios urbanos do que nas fazendas de café, cana e algodão, configurando uma espécie de separação agricultura-indústria" (M.ARTINS, 1979, cap. 1$)^{5}$.

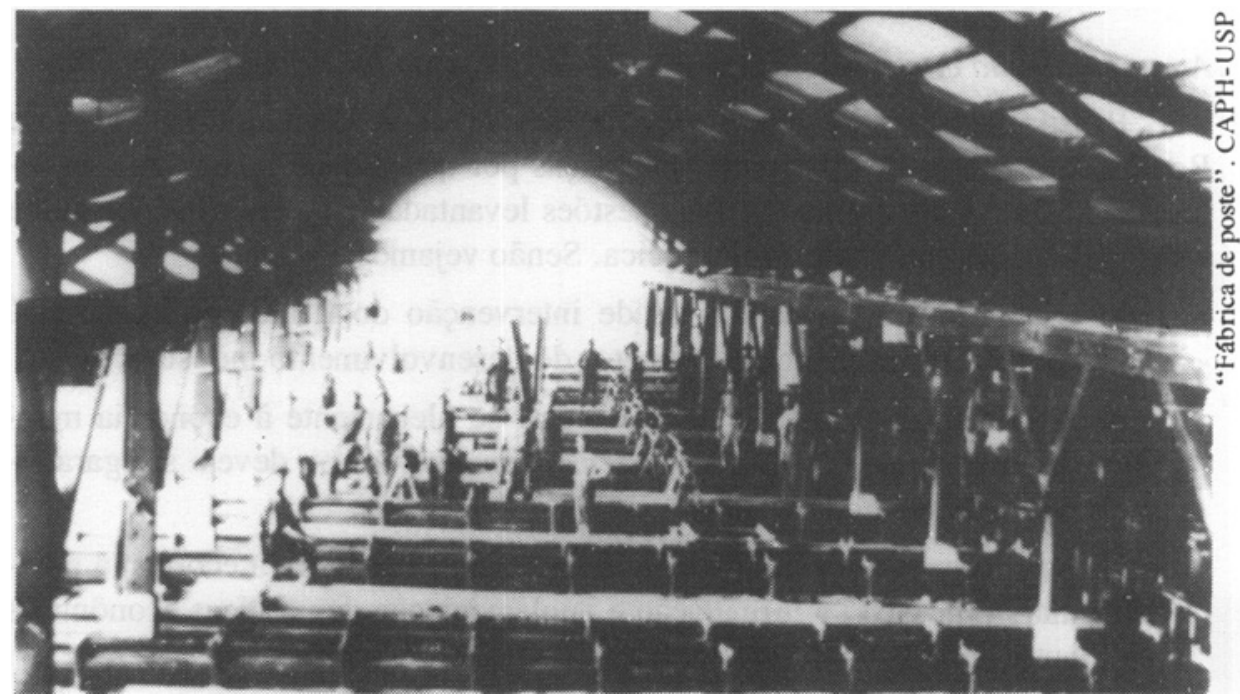

É claro que ao lado da questão err.pírica a ser resolvida, o tema em questão coloca problemas interpretativos importantes sobre a gênese da indústria e da burguesia industrial. Se a matriz da indústria é o comércio de importação (e a da burguesia industrial são os grandes comerciantes de importação), a questão oferece poucas dificuldades; se a indústria emerge de dentro da sociedade escravista, torna-se mais difícil entender como aparece o capitalista industrial e como se constitui a consciência burguesa (MARTINS, 1979, p. 107-14).

Nessa mesma linha de preocupação, pode-se formular a seguinte questão: na medida çue se coloca em dúvida que o regime de colonato possa ser caracterizado propriamente como trabalho assalariado (e sim como uma forma não capitalista de relaçōes de produção, pois o trabalhador produz diretamente seus meios de subsistência), a própria lógica do desenvolvimento industrial a partir de relaçōes capitalistas estabelecidas na produção cafeeira se torna questionável.

5 Este texto contém importantes comentários crfticos e sugestôes sobre o tema da Industrializaçäo em São Paulo. 
Estes dois últimos temas, relevantes para a compreensão da gênese da indústria no Brasil, merecem tratamento específico e mais alongado. Por isso, preferimos apenas mencioná-los para reiterar sua importância.

\section{Estudos regionais}

Ncs anos recentes verificou-se a produção de vários estudos sobre experiências regionais de industrialização. Até aqui, as grandes interpretaçōes do crescimento da indústria no Brasil pautaram-se por observar a experiência de São Paulo e Rio de Janeiro. Trata-se, obviamente, de visão parcial do processo, embora nesses dois estados se tenha concentrado a parcela mais importante da indústria na Primeira República. Parece certo, portanto, que os novos esforços de compreensão do desenvolvimento industrial poderão incorporar os resultados das pesquisas sobre experiências regionais de industrialização. Mesmo que as teses mais gerais nāo sejam modificadas, questōes como as apresentadas neste tópico serão discutidas sobre bases mais sólidas.

\section{A atualidade da controvérsia sobre a industrialização na Primeira República}

Penso que não há exagero em afirmar que, ao se completar cem anos de República e apesar das profundas mudanças por que passou a economia brasileira, mantêm-se atuais muitas das questōes levantadas pela controvérsia sobre a industrialização na Primeira República. Senāo vejamos:

a) Quais devem ser as formas de intervenção do Estado na economia? Qual sua eficácia como promotor do desenvolvimento industrial?

b) A economia brasileira deve integrar-se plenamente à economia mundial com base em suas vantagens comparativas ou devem ser garantidas reservas de mercado?

c) Qual o grau de subordinaçāo da economia brasileira à economia mundial? É possível a formulação e implementaçãc de políticas econômicas autônomas?

Estas são algumas das questōes presentes na controvérsia sobre a industrialização na Primeira República (e nos anos 30) e que hoje ainda aparecem como não-resolvidas no nível da sociedade. É óbvio: diferentes soluçōes expressam opçōes de diferentes grupos sociais em relaçāo aos temàs e em relaçāo aos modelos de desenvolvimento a serem implementados. Por esse motivo, no plano acadêmico ou na prática política, a controvérsia jamais se encerra, apenas é recolocada em outros termos.

\section{Referências Bibliografícas}

CARDOSO. F.H. 1960. Condições sociais da industrialização: o caso de São Paulo. Revista Brasiliense, (28), março/abril.

DEAN, W. 1971. A industrialização de São Paulo. São Paulo, DIFEL/EDUSP.

FISHLOW, A. 1972. Origens e conseqüências da substituição de importaçōes no Brasil. Estudos Econômicos. 2(6): 7-75, dezembro.

FURTADO, C. 1968. Forme.̧̧ão econômica do Brasil. 8. ed. São Paulo, Companhia Editora Nacional. 
LUZ, N.V. 1975. A luta pela industrialização do Brasil. 2. ed. São Paulo, Alfa-On ega.

MARTINS, J.S. 1973. Conde Matarazzo, o empresário e a empresa. 2. ed. São Paulo, Hucitec. 1979. O cativeiro da terra. São Paulo, Ciências Humanas.

MELLO, J.M.C. 1986. O capitalismo tardio. 4. ed. São Paulo, Brasiliense.

PELÁEZ, C.M. 1968. A balança comercial, a grande depressão e a industrializaçāo brasileira. Revista Brasileira de Economia. 2(1): 15-47.

PRADO, JR. C. 1970. História econômica do Brasil. 12. ed. São Paulo, Brasiliense.

SILVA, S. 1976. Expansão cafeeira e origens da industrialização no Brasil. São Paulo, Alfa-Omega.

SIMONSEN, R.C. 1973. Evoluçāo industrial do Brasil e outros estudos. São Yaulo, Companhia Editora Nacional/EDUSP.

SODRÉ, N.W. 1967. Formaçâo histórica do Brasil. 4. ed. São Paulo. Brasiliense.

VERSIANI, F. 1982. Before the depression: brazilian industry in the 1920's. Brasilia, Fundaçäo Universidade de Brasilia.

VERSIANI, F.R. e VERSIANI, M.T.R.O. 1977. A industrialização brasileira antes de 1930: uma contribuição. In: VERSIANI, F.R. e BARROS, J.R.M., org. Formaşão econômica do Brasil. São Paulo.

VILLELA, A.V. e SUZIGAN, W. 1973. Política do govemo e crescimento da economia brasileira, 1889-1945. Rio de Janeiro, IPEA/INPES.

\section{Bibliografia}

CANO, W. Raízes da concentração industrial em São Paulo. Rio de Janeiro/São Paulo, DIFEL, 1977.

COHN, G. Protlemas da industrialização no século XX. In: MOTA, C.G., org. Brasil em perspectiva. 2. ed. São Paulo, Difusão Européia do Livro, 1969.

FURT ADO, A. Formaşâo económica da América Latina. 2. ed. Rio de Janeiro, Lia Editor, 1970.

SILBER, S. Análise da política econômica e do comportamento da economia brasileira durante c período 1929/1939. In: VERSIANI, F.R. e BARROS, J.R.M., org. Formaşão econômica do Brasil. São Paulo, 1977.

SUZIGAN, W. Indústria brasileira. São Paulo, Brasiliense, 1986.

Flávio Azevedo Marques de Saes é professor associado do Departamento de Economia da FEA/USP e participante do Ciclo de Seminários "Cem anos de República: continuidade e mudança", 1989, do IEA. 